\title{
КРИМІНОЛОГІЧНА ХАРАКТЕРИСТИКА ТА ЗАПОБІГАННЯ КОРИСЛИВИМ ЗЛОЧИНАМ ПРОТИ ВЛАСНОСТІ У ВЕЛИКОМУ МІСТІ ПРИЧОРНОМОРСЬКОГО РЕГІОНУ
}

Остроглядов О.I.

\begin{abstract}
У cmammi представлені результати вивчення кримінологічної характеристики корисливим злочинам проти власності у великому місті Причорноморського регіону, узагальнені фактори детермінації цих правопорушень, окреслені основні напрями запобігання цим злочинам.
\end{abstract}

За результатами дослідження встановлено, що тільки в місті Одеса щорічно вчиняється 51\% (10 389) злочинів проти власності; у місті Миколаїв щорічно реєструється порядку 49\% (6201) посягань на власність, у місті Херсон реєструється один із трьох від усіх учинених у регіоні злочинів проти власності. Корисливі посягання на власність у великому місті характеризуються несприятливою динамікою та яскравими кількісно-якісними відмінностями. Максимальні параметри інтенсивності цих злочинів спостерігаються в місті Миколаєві з показниками 1274 злочини на 100000 населення, на другому місті опинилося місто Херсон - 1271 злочини на 100 000, mpeтє місце посіло місто Одеса із показниками 1028 злочинів на 100000 населення.

Сформульовано, що до найбільш вагомих факторів детермінації корисливих посягань на власність у великому місті належать такі: негативні процеси, пов'язані з урбанізацією; високий рівень безробітmя; соціальна нерівність серед населення; негативний вплив алкоголізму, зловживання алкоголем та наркотиками; висока концентрація у великих містах рецидивістів; негативний вплив оточуючого середовища; надмірна насиченість міського середовища незаконно придбаною зброєю; домінування в суспільстві установок на збагачення будь-якими шляхами; низький рівень викриття місць збуту викраденого майна; низький рівень розкриття крадіжок, грабежів, розбоїв, вимагань та шахрайств; неналежний захист житла громадян; невиправдана гуманізація кримінального законодавства; неналежна організація віктимологічної профілактики серед населення тощо.

Підвищення якості запобігання корисливим злочинам nроти власності у великому місті передбачає діяльність, спрямовану на покращення економічної cuтуації у великому місті, створення безпечного

с Остроглядов О. І., 2020 міського середовища шляхом розбудови міської інфраструктури, покращення благоустрою, налагодження освітлення, зменшення навантаження на міську автотранспортну систему, профілактика зловживання наркотиками та алкоголем, інформування населення про найбільш небезпечні місця та способи вчинення корисливих посягань на власність, доведення способів збереження майна від протиправних посягань, збільшення рівня розкриття корисливих злочинів проти власності, посилення інформаційно-аналітичного забезпечення роботи правоохоронних органів, обладнання вулиць міста системою відеоспостереження. Важлива роль у роботі правоохоронних органів відводиться збільшенню нарядів полічії у вечірній та нічний час; самостійна роль відводиться картографуванню маршрутів пересування злочинців і узагальнення даних про місця скоєння злочинів, потенційних місць збуту викраденого майна, систематизація адрес проживання осіб, схильних до вчинення чієї категорії правопорушень тощо.

Ключові слова: корислива злочинність проти власності, регіон, велике місто, Причорноморський регіон, детермінація злочинності у великому місті, запобігання злочинності.

Ostroglyadov 0. I. Criminological characteristic and prevention of mercenary crimes against property in a big city of the Black Sea region

The results of studying the criminological characteristics of mercenary crimes against property in a big city in the Black Sea region, the generalized factors of determination of these offenses are presented in the article, the main directions of prevention of these crimes are outlined.

According to the results of the investigation, it is established that only in the city of Odessa more than half of $51 \%$ $(10,389)$ crimes against property are committed annually; in Nikolaev about 49\% (6201) encroachments on property are annually registered; and in Kherson, one in three of all crimes against property committed in the region is registered. Mercenary encroachments on property are characterized by adverse dynamics and striking quantitative and qualitative differences in a big city. The maximum parameters of intensity of these crimes are observed in the city of Nikolaev with indicators of 1274 crimes per 100000 population; Kherson came in second place - 1274; 
and the third place was taken by Odessa with rates of 1028 crimes per 100000 population.

It is formulated that the most significant factors of determination mercenary encroachments on property in a big city include: negative processes associated with urbanization; high level of unemployment; social inequality among the population; negative impact of alcoholism, alcohol and drug abuse; high concentration of recidivists in large cities; negative impact of the environment; excessive saturation of the urban environment with illegally acquired weapons; domination in society of facilities to enrichment by any means; low level of exposing places of sale of stolen property; low level of disclosing thefts, robberies, assaults, extortions and frauds; inadequate protection of citizens' housing; unjustified humanization of criminal legislation; improper organization of victimological prophylaxis among the population, etc.

Improving the quality of preventing mercenary crimes against property in a big city involves activities aimed at: improving the economic situation in the big city; creating a safe urban environment by building urban infrastructure, improving of accomplishment, lighting adjustment; decreasing the burden on the urban transport system; prevention of drug and alcohol abuse; informing the population about the most dangerous places and ways of committing mercenary encroachments on property; proving ways to preserve property from illegal encroachments; increasing the level of solving mercenary crimes against property; strengthening information and analytical support for the work of law enforcement agencies; equipping the city streets with a video surveillance system. An important role in the work of law enforcement is given to increasing police squads in the evening and at night; an independent role is assigned to the mapping of routes of movement of criminals and generalization of data on places of commission of crimes, potential places of sale of stolen property, systematization of residence addresses of persons predisposed to this category of offenses, etc.

Key words: mercenary crime against property, region, big city, Black Sea region, determination of crime in a big city, crime prevention.

Постановка проблеми та її актуальність. Проблема вивчення та запобігання корисливій злочинності проти власності у великому місті набуває дедалі більшої актуальності. Це і невипадково, оскільки великі міста останніми роками стали осередками злочинності корисливої спрямованості, які посягають на власність. Насамперед це пов'язано із тим, що великі міста за своїми функціями виступають центрами соціального, економічного, культурного та політичного життя регіону. У них зосереджується більшість всіх процесів, які так або інакше пов'язані з життям конкретної області. Вони виступають соціальними магнітами для великої кількості населення, фінансових проце- сів, а отже, стають надзвичайно привабливими для різного роду антисоціальних процесів, у тому числі і корисливих посягань на власність. Наведене зумовлює, з одного боку, підвищений інтерес до теми міської злочинності, а з іншого - призводить до необхідності актуалізації наукових досліджень, присвячених вивченню феномена запобігання корисливим злочинам проти власності у великих містах України.

Аналіз наукових досліджень і публікацій. Питанням аналізу та запобігання злочинності у великих містах, в тому числі і корисливих злочинів проти власності, в різні часи приділяли увагу такі вчені, як Б.М. Головкін, В.В. Голіна, О.М. Джужа та ін. В.В. Василевич та Є.М. Моісеєв вивчали характеристику і розробляли заходи запобігання загальнокримінальній корисливій злочинності [17, с. 124-144; 14]. В.С. Батиргареєва вивчала вказаний феномен у ході вивчення кримінологічних проблем розбоїв, а пізніше - рецидивної злочинності [10; 11]. О.Г. Кулик, І.В. Наумова, А.А. Бова досліджували соціально-демографічні та кримінологічні ознаки осіб, які вчиняли корисливі злочини проти власності [18, с. 282-290]. С.В. Албул розробив кримінологічну характеристику корисливо-насильницьких злочинів щодо іноземних громадян та запропонував шляхи зниження рівня віктимності вказаної категорії громадян [2]. Є.Ф. Азаров вивчав цю тему в межах запобігання корисливим злочинам на залізничному транспорті [1]; С.М. Алфьоров аналізував корисливу злочинність у розрізі аналізу та запобігання злочинності у курортному регіоні [3]. А.М. Бабенко приділяв увагу вивченню регіональних особливостей корисливої злочинності проти власності [4-8]. Незважаючи на це, проблема кримінологічного аналізу та запобігання корисливої злочинності проти власності у великих містах Причорноморського регіону не була предметом самостійного аналізу. Це і зумовило вибір теми цієї частини нашого дослідження.

Метою статті $є$ надання кримінологічної характеристики корисливої злочинності проти власності у великому місті Причорноморського регіону України та розроблення на цій основі системи запобігання цим злочинам.

Виклад основного матеріалу. Загальновідомо, що кримінологічна характеристика є однією з центральних категорій і обов'язковим елементом будь-якого кримінологічного дослідження. Саме інформація, представлена у рамках кримінологічної характеристики злочинності, закладається в основу інформаційно-аналітичного забез- 
печення діяльності правоохоронних органів з їі запобігання.

У наукових дослідженнях, які безпосередньо присвячені вивченню корисливої злочинності у містах, кримінологічною характеристикою охоплюється кількісні та якісні показники злочинності (структура, динаміка, інтенсивність, географія і т.д.), статистичні відомості, що характеризують осіб, які вчиняють злочини на території великих міст, детермінанти протиправної діяльності на територіях українських міст [10, с. 32-34; 12, с. 78; 3, с. 28-29]. Саме ця інформація покладається в основу під час розробки системи запобігання досліджуваному виду антисуспільної діяльності.

За даними статистики Генеральної прокуратури України, злочини проти власності довгі роки посідають перше місце серед усіх зареєстрованих злочинів у нашій країні. Серед 444130 злочинів, зареєстрованих в Україні у 2019 р., понад половину (257 608) становили злочини саме цієї категорії. I хоча за останні два роки їх реєстрація зменшилася з 303850 злочинів у 2018 р. до 257608 у 2019 р. (- 15\%), їх питома вага в загальній структурі злочинності протягом останніх п'яти років залишається доволі високою і у середньому становить 60\% [8, с. 327-330; 7, с. 63-64]. Практично кожен десятий злочин, який посягає на відносини у сфері власності (13,3\%), вчиняється в Одеській - 14147 (5,5\%), Миколаївській - 9365 (3,6\%) або у Херсонській - 10772 (4,2\%) області, більшість із них належить до категорії корисливих чи корисливо-насильницьких злочинів (Табл. 1).

Корислива злочинність проти власності характеризується нерівномірністю їі поширення на території Причорноморського регіону. Найбільш складною ситуація у сфері посягань на власність спостерігається в Одеській області, де щорічно вчиняється 10321 (73\%) крадіжок (у тому числі квартирних $1478(10,4 \%))$, грабежів - 1071 (7,6\%), розбоїв - 215 (1,5\%), вимагань - 91 (0,64\%) та шахрайств - 1431 (10\%). Загалом корисливі посягання на власність у цьому регіоні становлять близько 90\% від усіх зареєстрованих злочинів у сфері власності. Друге місце за складністю криміногенної обстановки протягом останніх років належить Миколаївській області, де реєструється 7935 (74\%) крадіжок (353, тобто 4,5\%, з квартир), 400 (3,7\%) грабежів, 57 (0,5\%) - розбоїв, 20 (0,18\%) - вимагань, і 1730 (16\%) шахрайств. Інша картина простежується в Херсонській області, де всі злочини проти власності налічують 9365 (64\%), з яких крадіжки становлять 83\% (7827), грабежі - 2,8\% (262), розбої - 0,74\% (69), вимагання - 0,23\% (22) і шахрайства - 8,3\% (780) (табл. 1).

Стан злочинності у досліджуваному регіоні істотно зумовлюється криміногенною обстановкою у великих містах - Одесі, Миколаєві та Херсоні, які $є$ не лише центрами впливу на соціальноекономічне життя регіону, а і виявилися осередками концентрації і генерації всіх без виключення (в тому числі і корисливих злочинів проти власності) видів злочинів. За даними місцевих правоохоронних органів, тільки у місті Одеса щорічно вчиняється 51\% (10 389) злочинів проти власності. Схожа ситуація відбувається в місті Миколаїв, де щорічно реєструється порядку 49\% (6201) посягань на власність. I лише у місті Херсон реєструється один із трьох від усіх учинених у регіоні злочинів проти власності.

Характеристика розрахованих нами індексів корисливої злочинності проти власності у великих містах Причорномор'я дала змогу встановити, що максимальні параметри інтенсивності цих злочинів спостерігаються в місті Миколаєві з показни-

Таблиця 1

Структура корисливих злочинів проти власності

у Причорноморському регіоні материкової України у 2019 р.

\begin{tabular}{|c|c|c|c|c|c|c|c|c|}
\hline $\begin{array}{c}\text { Peгіон / вид } \\
\text { злочинів }\end{array}$ & $\begin{array}{c}\text { Загальна } \\
\text { кількість } \\
\text { злочинів } \\
\text { проти } \\
\text { власності } \\
\end{array}$ & $\begin{array}{c}\text { Питома вага } \\
\text { регіону } \\
\text { у загальній } \\
\text { структурі (\%) }\end{array}$ & Крадіжки & $\begin{array}{l}\text { Крадіжки } \\
\text { з квартир }\end{array}$ & Грабежі & Розбої & Вимагання & Шахрайства \\
\hline По Україні & 257608 & $100 \%$ & \begin{tabular}{|l|}
197564 \\
$77 \%$ \\
\end{tabular} & $\begin{array}{l}16634 \\
9 \% \\
\end{array}$ & $\begin{array}{l}11160 \\
4,33 \% \\
\end{array}$ & $\begin{array}{l}1883 \\
0,73 \%\end{array}$ & $\begin{array}{l}730 \\
0,28 \% \\
\end{array}$ & $3235812,6 \%$ \\
\hline Одеська & 14147 & $5,5 \%$ & $\begin{array}{l}10321 \\
73 \%\end{array}$ & $\begin{array}{l}1478 \\
10,4 \%\end{array}$ & $\begin{array}{l}1071 \\
7,6 \%\end{array}$ & $\begin{array}{l}215 \\
1,5 \%\end{array}$ & $\begin{array}{l}91 \\
0,64 \%\end{array}$ & $\begin{array}{l}1431 \\
10 \%\end{array}$ \\
\hline Херсонська & 9365 & $3,6 \%$ & $\begin{array}{l}7827 \\
83 \% \\
\end{array}$ & $\begin{array}{l}342 \\
4,4 \% \\
\end{array}$ & $\begin{array}{l}262 \\
2,8 \%\end{array}$ & $\begin{array}{l}69 \\
0,74 \% \\
\end{array}$ & $\begin{array}{l}22 \\
0,23 \% \\
\end{array}$ & $\begin{array}{l}780 \\
8,3 \% \\
\end{array}$ \\
\hline Миколаївська & 10772 & $4,2 \%$ & $\begin{array}{l}7935 \\
74 \%\end{array}$ & $\begin{array}{l}353 \\
4,5 \%\end{array}$ & $\begin{array}{l}400 \\
3,7 \%\end{array}$ & $\begin{array}{l}57 \\
0,5 \%\end{array}$ & $\begin{array}{l}20 \\
0,18 \%\end{array}$ & $\begin{array}{l}1730 \\
16 \%\end{array}$ \\
\hline
\end{tabular}



та науково-методичне забезпечення

ками 1274 злочини на 100000 населення, на другому місті опинилося місто Херсон - 1271 злочини на 100 000, і третє місце посіло місто Одеса із показниками 1028 злочинів на 100000 населення. Така ситуація $\epsilon$ невипадковою, а простежується вже протягом багатьох років. За даними соціологічних досліджень, південні міста Херсон, Миколаїв та Одеса традиційно належать до найбільш небезпечних саме через високі показники грабежів, розбоїв, вимагань та шахрайств [13; 15; 21].

Заслуговує на увагу той факт, що більшість осіб досліджуваної категорії антисуспільних дій $\epsilon$ чоловіками (89\%) і лише $11 \%$ - жінками. Разом із цим статевий розподіл внеску чоловіків та жінок у загальній чисельності злочинців у містах Причорномор'я $\epsilon$ різним. Так, якщо у Миколаєві (88,2\% : 11,8\%) та Одесі (88\% : 12\%) співвідношення між чоловіками та жінками є приблизно однаковим, то у Херсоні при домінуванні у структурі злочинців питомої ваги чоловіків $(84,25 \%)$ до жінок (15,75\%), загальний внесок жінок у корисливу злочинність проти власності $\epsilon$ помітно вищим. Найвища криміногенна активність осіб, які вчинили корисливі злочини проти власності у великих містах Причорномор'я, нами зафіксована у таких вікових групах: від 18 до 28 років (Херсон 24\%, або 472 особи; Миколаїв - 32\%, або 627 осіб; Одеса - 36,3, або 1200 осіб); від 29 до 39 років (Херсон - 39,4\%, або 678 осіб; Миколаїв - 36,5\%, або 714 осіб; Одеса - 36,7, або 1214 осіб); від 40 до 54 років (Херсон - 28,5\%, або 550 осіб; Миколаїв 21\%, або 407 осіб; Одеса - 16,4\%, або 543 осіб). Щодо освітнього рівня осіб, як вчиняють корисливі злочини проти власності у великих містах, то в їх структурі переважають ті, які мають низький освітній рівень: із повною загальною середньою та базовою загальною середньою освітою у Херсоні злочини вчиняли 80\%, в Одесі - 77,5\% і у Миколаєві - 71\% осіб. Професійно технічна освіта зафіксована у Херсоні у 15\%, в Миколаєві у $20 \%$ і в Одесі - у 9,7\% осіб. Херсон (6\%) та Одеса (5,4\%) відрізняються більшою питомою вагою осіб із повною вищою і базовою вищою освітою порівняно із Миколаєвом, де таких налічувалося лише 2,8\%. Що стосується соціально-рольових ознак, то, за даними емпіричних досліджень, більшість осіб, які вчиняють корисливі посягання на власність, неодружені і незаміжні особи - 64\%, розлучені або вдівці - 7,4\%. Лише чверть $(25,7 \%)$ осіб до вчинення злочину біли одружені або перебували у фактичних шлюбних відносинах [10, с. 81]. Лише одна з десяти осіб на момент вчинення крадіжки, грабежу, розбою, вимагання або шахрайства мала роботу. В Одесі їх налічувалося 11\%, у Херсоні 10,4\%, у Миколаєві - 14\%. Як правило, злочинці були зайняті на низькооплачуваній, малокваліфікованій роботі, яка не вимагає істотних освітніх або розумових здібностей.

Чисельні кримінологічні дослідження вказують на те, що крадіжки, грабежі, розбої, вимагання та шахрайства $€$ найбільш типовими злочинами великих міст України, які вчиняються практично у будь-яку пору року. Разом із цим інтенсивність їх вчинення знаходиться у прямій залежності від часових, сезонних та територіальних факторів. Наприклад, грабежі та розбої в громадських місцях вчиняються переважно у вечірній та нічний час, а з проникненням у квартири (в тому числі і крадіжки) здебільшого зранку та вдень. Більшість квартирних крадіжок у великому місті учиняють у ранковий час (у період з 9:00 до 13:00 - близько 70\% діянь). Саме в цей час багато громадян перебувають на роботі, у навчальних закладах, домогосподарки здійснюють покупки. Решту крадіжок учиняють у вечірній час, переважно $з$ 22:00 до 24:00. Найбільш криміногенними сезонами для грабежів у спальних районах $\epsilon$ зима та осінь (54\%), а для центральних районів курортного міста - навпаки, влітку вдень та вночі (62\%) [17, с. 125-128; 16, с. 159-162; 9, с. 7-9]. Проведеним дослідженням не зафіксовано істотних сезонних відмінностей для розбоїв та вимагань. Разом із цим виявлено особливості, які пов'язані 3 характером архітектурної забудови та інфраструктури: найчастіше грабежі, розбійні напади та вимагання вчиняються на територіях із нерозвиненою структурою - тихі вулиці, недалеко від зупинок та транспорту в погано освітлених «спальних районах», а також у центральних із великою кількістю шляхів відходу [17, с. 125-128; 16, с. 159-162; 9, с. 7-9]. «Вуличні» шахрайства у великому місті Причорномор'я $є$ найбільш характерними влітку - протягом курортного сезону, у той час як для вчинення шахрайств із нерухомістю у комерційній сфері та кібершахрайств не спостерігається помітно вираженої сезонної та часової залежності [20, с. 92-115]. Представлена інформація може виявитися корисною для інформаційно-аналітичного забезпечення роботи правоохоронних органів для підвищення ефективності в запобіганні корисливих злочинів проти власності в умовах великого міста Причорноморського регіону материкової України.

Вивчення наукової літератури дало змогу виділити причинний комплекс корисливих злочинів проти власності у великих містах Причорномор'я 
України. До найбільш вагомих факторів належать: негативні процеси, пов'язані з урбанізацією; високий рівень безробіття; соціальна нерівність серед населення; негативний вплив алкоголізму, зловживання алкоголем та наркотиками; висока концентрація у великих містах рецидивістів; негативний вплив оточуючого середовища; надмірна насиченість міського середовища незаконно придбаною зброєю; домінування в суспільстві установок на збагачення будь-якими шляхами; низький рівень викриття місць збуту викраденого майна; низький рівень розкриття крадіжок, грабежів, розбоїв, вимагань та шахрайств; неналежний захист житла громадян; невиправдана гуманізація кримінального законодавства; неналежна організація віктимологічної профілактики серед населення тощо [17, с. 137-143; 19, с. 197; 4, с. 201-268].

3 огляду на це ефективне запобігання досліджуваному виду злочинності, насамперед, полягає у підвищенні ефективності загальносоціального, спеціально-кримінологічного й індивідуального запобігання. У цьому сенсі не остання роль відводиться підвищенню якості планування та програмування заходів із запобігання корисливій злочинності проти власності на території окремого міста. Оскільки, за даними нашого дослідження, корисливі злочини проти власності становлять більшість правопорушень великого міста, на їх профілактику і запобігання має спрямовуватися основна частина всіх зусиль правоохоронних органів міста.

До найбільш ефективних заходів підвищення ефективності запобігання цим правопорушенням слід зарахувати покращення економічної ситуації у великому місті, створення безпечного міського середовища шляхом розбудови міської інфраструктури, покращення благоустрою, налагодження освітлення, зменшення навантаження на міську автотранспортну систему, профілактика зловживання наркотиками та алкоголем, інформування населення про найбільш небезпечні місця та способи вчинення корисливих посягань на власність, доведення способів збереження майна від протиправних посягань, збільшення рівня розкриття корисливих злочинів проти власності, посилення інформаційно-аналітичного забезпечення роботи правоохоронних органів, обладнання вулиць міста системою відеоспостереження. Важлива роль у роботі правоохоронних органів відводиться збільшенню нарядів поліції у вечірній та нічний час; самостійна роль відводиться картографуванню маршрутів пересування злочинців і узагальнення даних про місця скоєння злочинів, потенційних місць збуту викраденого майна, систематизація адрес проживання осіб, схильних до вчинення цієї категорії правопорушень тощо. Сподіваємося, що представлені результати виявляться корисними для правоохоронних органів і сприятимуть зменшенню рівня корисливих посягань на власність у великому місті.

Висновки. Великі міста Причорноморського регіону останніми роками виявилися осередками концентрації і генерації корисливих злочинів проти власності. За даними місцевих правоохоронних органів, тільки в місті Одеса щорічно вчиняється 51\% (10 389) злочинів проти власності; у місті Миколаїв щорічно реєструється порядку 49\% (6201) посягань на власність, у місті Херсон реєструється один із трьох від усіх учинених у регіоні злочинів проти власності. Корисливі посягання на власність у великому місті характеризуються несприятливою динамікою та яскравими кількісно-якісними відмінностями. Максимальні параметри інтенсивності цих злочинів спостерігаються в Миколаєві з показниками 1274 злочини на 100000 населення, на другому місті опинилося місто Херсон - 1271 злочини на 100 000, і третє місце посіло місто Одеса з показниками 1028 злочинів на 100000 населення.

До найбільш вагомих факторів детермінації корисливих посягань на власність у великому місті належать такі: негативні процеси, пов'язані з урбанізацією; високий рівень безробіття; соціальна нерівність серед населення; негативний вплив алкоголізму, зловживання алкоголем та наркотиками; висока концентрація у великих містах рецидивістів; негативний вплив оточуючого середовища; надмірна насиченість міського середовища незаконно придбаною зброєю; домінування у суспільстві установок на збагачення будь-якими шляхами; низький рівень викриття місць збуту викраденого майна; низький рівень розкриття крадіжок, грабежів, розбоїв, вимагань та шахрайств; неналежний захист житла громадян; невиправдана гуманізація кримінального законодавства; неналежна організація віктимологічної профілактики серед населення тощо.

Підвищення якості запобігання корисливим злочинам проти власності у великому місті передбачає діяльність, спрямовану на покращення економічної ситуації у великому місті, створення безпечного міського середовища шляхом розбудови міської інфраструктури, покращення благоустрою, налагодження освітлення, зменшення навантаження на міську автотранспортну 

та науково-методичне забезпечення

систему, профілактику зловживання наркотиками та алкоголем, інформування населення про найбільш небезпечні місця та способи вчинення корисливих посягань на власність, доведення способів збереження майна від протиправних посягань, збільшення рівня розкриття корисливих злочинів проти власності, посилення інформаційно-аналітичного забезпечення роботи правоохоронних органів, обладнання вулиць міста системою відео спостереження. Важлива роль у роботі правоохоронних органів відводиться збільшенню нарядів поліції у вечірній та нічний час; самостійна роль відводиться картографуванню маршрутів пересування злочинців і узагальненню даних про місця скоєння злочинів, потенційних місць збуту викраденого майна, систематизації адрес проживання осіб, схильних до вчинення цієї категорії правопорушень тощо.

\section{Література}

1. Азаров Є.Ф. Запобігання корисливим злочинам на пасажирському залізничному транспорті України : автореф. дис. ... канд. юрид. наук : 12.00.08. Харків, 2017. 20 с.

2. Албул С.В. Кримінологічна характеристика корисливо-насильницьких злочинів відносно іноземних громадян: дис. ... канд. юрид. наук : 12.00.08. Одеса, 2005. 194 с.

3. Алфьоров С.М. Діяльність органів внутрішніх справ по протидії злочинності у курортних регіонах (кримінологічне дослідження на матеріалах Запорізької області) [Текст] : дис. ... канд. юрид. наук : 12.00.08. Харків, 2003. 197 с.

4. Бабенко А.М. Запобігання злочинності в регіонах України: концептуально-методологічний та праксеологічний вимір : монографія. Одеса : ОДУВС, 2014. 416 с.

5. Бабенко А.М. Регіональні особливості злочинності у містах та сільських районах Запорізької, Дніпропетровської та Харківської областей. Питання боротьби зі злочинністю : збірник наук. пр. / редкол.: В.І. Борисов та ін. Харків : Право, 2018. С. 42-60

6. Бабенко А.М. Територіально-просторовий аналіз злочинності у населених пунктах Одеської області. Вісник Асоціації Кримінального права України. 2017. № 2(9). URL: http://nauka.nlu.edu.ua/ wp-content/uploads/2017/12/11_Babenko.pdf.

7. Бабенко А.М., Конопельський В.Я. Чекмарьова І.М. Кримінологічна характеристика та запобігання злочинності у прикордонних регіонах Причорномор'я материкової України : монографія. Харків : Право, 2019. 264 с.
8. Бабенко А.М., Остроглядов О.І. Деякі питання кримінологічної характеристики корисливої злочинності проти власності у Причорноморських регіонах материкової України. Інтелектуальна власність i право на шляху до сталого розвитку України : матеріли II Міжнародної науково-практичної конференції, Київ, 19 квітня 2019 р. Київ : ФОП Кандиба Т.П., 2019. С. 327-330.

9. Басков А.В. Виктимологическая профилактика корыстно-насильственных преступлений, совершаемых в общественных местах : дис. ... канд. юрид. наук : 12.00.08. Москва, 2010. 180 с.

10. Батиргареєва В.С. Кримінологічна характеристика та попередження розбоїв, поєднаних із проникненням у житло : монографія. Харків : Одіссей, 2003. 256 c.

11. Батиргареєва В.С. Рецидивна злочинність в Україні: соціально-правові та кримінологічні проблеми [Текст] : монографія. Харків : Право, 2009. 576 с.

12. Бойко В.В. Кримінологічна характеристика та запобігання тяжким насильницьким злочинам проти життя та здоров'я особи в особливо великих містах України : дис. ... канд. юрид. наук : 12.00.08. Харків, 2018. 280 с.

13. Визначені найбільш небезпечні регіони України. 2017. URL: https://zik.ua/news/2014/02/07/ vyznacheni_naybilsh_nebezpechni_regiony_ukrainy_ doslidzhennya_459062 (дата звернення: 10.02.2020).

14. Віктимологія : навч. посібник / В.В. Голіна, Б.М. Головкін, М.Ю. Валуйська та ін.; за ред. В.В. Голіни і Б.М. Головкіна. Харків : Право, 2017. 308 с.

15. Дожились: Одесса один из самых опасных для жизни городов по мнению украинцев. 2019. URL: https://od.vgorode.ua/news/24/306631dozhylys-odessa-odyn-yz-samykh-opasnykh-horodovdlia-zhyzny-po-mnenyui-ukrayntsev (дата звернення: 10.02.2020).

16. Копилова М. Віктимологічний аспект профілактики злочинів проти власності на курортах АР Крим. Підприємництво. Господарство. Право. 2010. № 9. С. 159-162.

17. Кримінологічна віктимологія: навч. посібник / Моiсеєв Є.М., Джужа О.М., Василевич В.В. та ін.; за заг. ред. О.М. Джужі. Київ : Атіка, 2006. 352 с.

18. Кулик О.Г., Наумова І.В., Бова А.А. Злочинність в Україні: фактори, тенденції, протидія (2002-2014 рр.) : монографія. Київ : ДНДІ МВС Україн, 2015. 364 с.

19. Ландышев С.В. Скородумов Н.А. Корыстнонасильственные преступления: криминологическая характеристика и предупреждение органами внутренних дел. Вестник КГУ им. Н.А. Некрасова. 2014. № 5. С. 197-200. 
Протидія злочинності: проблеми практики та науково-методичне забезпечення

20. Лефтеров Л.В. Запобігання підрозділами Національної поліції шахрайству, що вчиняється 3 використанням засобів електронних комунікацій : дис. ... канд. юрид. наук : 12.00.08. Одеса : Одеський державний університет внутрішніх справ, 2019. $284 \mathrm{c}$.

21. Николаев и Херсон - самые опасные города Украины, - рейтинг Фокуса. 2020. URL: https:// focus.ua/ukraine/441227-nikolaev_i_kherson_samye_

opasnye_goroda_ukrainy_reiting_fokusa (дата звернення: 10.02.2020).

Остроглядов О. І., підполковник поліціі, Начальник Суворовського районного відділу поліції в м. Одесі Головного управління Національної поліціі в Одеській області 